\title{
PRÓBA ANALIZY PORÓWNAWCZEJ LITEWSKIEJ GOSPODARKI FOLWARCZNO-PAŃSZCZYŹNIANEJ I LATYNOAMERYKAŃSKIEJ GOSPODARKI HACJENDOWEJ OD II POŁOWY XVIII DO II POŁOWY XIX WIEKU W KONTEKŚCIE KAPITALISTYCZNEGO SYSTEMU-ŚWIATA
}

ABSTRACT. Darius Žiemelis, Próba analizy porównawczej litewskiej gospodarki folwarczno-pańszczyźnianej i latynoamerykańskiej gospodarki hacjendowej od II połowy XVIII do II połowy XIX wieku w kontekście kapitalistycznego systemu-świata [An Attempt at Comparative Analysis of Lithuanian Manorial-Serf Economy and Hacienda Economic System of Latin America from the Second Half of $18^{\text {th }}$ to the Second Half of the $19^{\text {th }}$ Century in the Context of Capitalist World System], edited by K. Brzechczyn "Człowiek i Społeczeństwo" vol. XLII: Modelowanie świata społecznego. Założenia - rekonstrukcje - analizy [On Modeling of Social World: Assumptions - Reconstructions - Analysis], Poznań 2016, pp. 135-160, Adam Mickiewicz University Press. ISSN 0239-3271.

The paper for the first time in historiography compares the Lithuanian manorial-serf economy and Latin American hacienda economic systems in the second half of the $18^{\text {th }}$ century - the second half of the $19^{\text {th }}$ century in the context of the capitalist world system (CWS). The main focus will be on the explication in macro level of similarities and differences of structures and development trends of these systems. The analyzed period - is the stage of both the dominance and intensification of manorial-serf economy in Lithuania and predominance and intensification of hacienda economy in Latin American countries and it was determined by the same factor of the industrial revolution. The study confirms the thesis that these economic systems belonged to typologically close economic type (were focused on the serfdom method of production) in the global division of labor. It shows that both Lithuanian manorial-serf economy and haciendas of Latin America were not typical feudal enterprises, but had only peripheral capitalism features.

Darius Žiemelis, Mykolas Romeris University, Institute of Philosophy and Humanities, Ateities st. 20, LT-08303 Vilnius, Lithuania, e-mail: dariusziemelis@inbox.It 


\section{Wprowadzenie}

Dwadzieścia pięć lat litewskiej niepodległości uwydatniło pewne tendencje i kierunki badań w naukach historycznych tego kraju. Strukturalnie historiografia litewska stała się częścią historiografii europejskiej, jednakże zachowuje ona nadal (tak jak inne nauki humanistyczne i społeczne) lituanistyczno-centryczny charakter. Jest tak nie tylko z powodu „młodzieńczości” tych nauk. Od samego bowiem początku ich instytucjonalizacji i profesjonalizacji, co dokonało się w okresie międzywojennej niepodległości litewskiego państwa, ich jawną misją (z konieczności „ukrytą” w okresie sowieckim) było udowodnienie światu, że Litwa jest nie tylko geograficzną, ale i społeczno-kulturową kategorią. Pomyślne wypełnienie tej misji i integracja Litwy ze wspólnotą europejskich państw i narodów, jak twierdzi najbardziej znany litewski socjolog Zenonas Norkus, daje możliwość unowocześnienia programu nauk humanistycznych i społecznych tego kraju oraz szansę na poszukiwanie nowych sposobów badania historii i współczesności Litwy ${ }^{1}$. Oznaki tej odnowy są już dziś widoczne w litewskich naukach historycznych. Widzimy bowiem stopniowy rozkwit badań, które rozpatrują litewską historię z perspektywy regionalnej ${ }^{2}$, globalnej ${ }^{3}$ i cywilizacyjnej ${ }^{4}$. Oprócz historiografii skupionej na dziejach narodu zaczynają pojawiać się badania historii powszechnej ${ }^{5}$, które w europejskiej historiografii są dawno upowszechnioną praktyką ${ }^{6}$. Jednak zgodnie z międzynarodowymi tendencjami potencjalnie największa odnowa nauk historycznych wiąże

${ }^{1}$ Z. Norkus, Kokia demokratija, koks kapitalizmas? Pokomunistinè transformacija Lietuvoje lyginamosios istorinès sociologijos požiūriu, Vilniaus universiteto leidykla, Vilnius 2008, s. 13, 52.

${ }^{2}$ E. Gudavičius, Lietuvos istorija, t. 1: Nuo seniausiu laiku iki 1569 metu, Lietuvos rašytojų sajungos leidykla, Vilnius 1999.

${ }^{3}$ D. Žiemelis, Feudalism or Peripheral Capitalism?: Socio-Economic History of the Polish-Lithuanian Commonwealth in the $16^{\text {th }}-18^{\text {th }}$ Centuries, Lap Lambert Academic Publishing, Saarbrücken 2011.

${ }^{4}$ A. Bumblauskas, Wielkie Księstwo Litewskie: wspólna historia, podzielona pamięć, Muzeum Historii Polski, Warszawa 2013.

${ }^{5}$ N. Babinskas, Moldova XIV a. viduryje - XVI a. viduryje kaip socialinès struktūros tipologijos problema (daktaro disertacija), Humanitariniai mokslai, istorija (05 H), Vilniaus universitetas, Vilnius 2010.

${ }^{6}$ W Polsce przykładem tego typu badań jest praca: K. Brzechczyn, O wielości linii rozwojowych w procesie historycznym. Próba interpretacji ewolucji społeczeństwa meksykańskiego, Wyd. Naukowe UAM, Poznań 2004. 
się z historią porównawczą7. Główną zaletą ujęcia porównawczego jest poszerzanie horyzontu myślenia historycznego za pomocą zarówno lokalnej, jak i subkontynentalnej perspektywy. To z kolei umożliwia nową interpretację przeszłości naszego regionu w szerokim, globalno-cywilizacyjnym (metacywilizacyjnym) kontekście historycznym oraz bardziej adekwatne osadzenie i ocenienie badanego fenomenu. Jak widzimy, historyczne badania porównawcze są na Litwie w stadium początkowym ${ }^{8}$, a za klasyka wschodzącego litewskiego nurtu socjologii historyczno-porównawczej uznawany jest Zenonas Norkus ${ }^{9}$.

7 Zob. klasyczne ujęcia: T. Skocpol, States and Social Revolutions: A Comparative Analysis of France, Russia, and China, Cambridge University Press, Cambridge 1979; P. Kolchin, Unfree Labor: American Slavery and Russian Serfdom, Belknap Press of Harvard University Press, Cambridge, Mass. 1987; A. Przeworski, Democracy and the Market: Political and Economic Reforms in Eastern Europe and Latin America, Cambridge University Press, Cambridge 1991; B.S. Silberman, Cages of Reason: The Rise of the Rational State in France, Japan, the United States, and Great Britain, University of Chicago Press, Chicago 1993; S.D. Bowman, Masters and Lords: Mid-19th-Century U.S. Planters and Prussian Junkers, Oxford University Press, New York 1993; R. Biernacki, The Fabrication of Labor: Germany and Britain 1640-1914, University of California Press, Berkeley 1995; A.W. Marx, Making Race and Nation: A Comparison of South Africa, the United States, and Brazil, Cambridge University Press, Cambridge 1998; K. Pomeranz, The Great Divergence: China, Europe, and the Making of the Modern World Economy, Princeton University Press, Princeton 2000.

${ }^{8}$ A. Anušauskas, Ginkluotos kovos dèl Baltijos šalių ir Vakarų Ukrainos nepriklausomybès lyginamoji analizé, „Genocidas ir rezistencija” 2/1997, ss. 14-18; S. Pivoras, Lietuviu ir latviu pilietinés savimonés raida: XVIII a. pabaiga - XIX a. pirmoji pusé (lyginamasis aspektas), Vytauto Didžiojo universiteto leidykla, Vilnius 2000; K. Antanaitis, Sovietiné Lietuvos, Latvijos ir Estijos nomenklatūra (1953-1990 m.): dèsningumai ir ypatumai (daktaro disertacija), Humanitariniai mokslai, istorija (05 H), Vytauto Didžiojo Universitetas, Kaunas 2001; Z. Butkus, Valstybiniai perversmai Baltijos šalyse (1926 ir 1934 m.): panašumai ir skirtumai, „Lietuvos istorijos studijos” 18/2006, ss. 69-81.

${ }_{9}$ Z. Norkus, On Baltic Slovenia and Adriatic Lithuania. A Qualitative Comparative Analysis of Patterns in Post-Communist Transformation, Apostrofa/CEU Press, Vilnius 2012; idem, Непроголошена імперія: Велике князівство Литовське з погляду порівняльно-історичної соціології імперій, Критика, Київ 2016; idem, Imperium litewskie w międzyjednostkowych społecznościach i systemach politycznych: studium przypadku, „Politeja” 2/2011, ss. 129-154; idem, The Grand Duchy of Lithuania in the Retrospective of Comparative Historical Sociology of Empires, „World Political Science Review” 3(4)/2007, ss. 1-41. Zob. również rec.: K. Brzechczyn, Wzorce postkomunistycznej transformacji, „Środkowoeuropejskie Studia Polityczne” 4/2014, ss. 231-241. 
Niniejszy artykuł, należący do socjologii historyczno-porównawczej ${ }^{10}$, jest elementem „komparatystycznego zwrotu” zaczynającego się właśnie w litewskich naukach historycznych. Opiera się on na założeniu, że porównanie Litwy z krajami typologicznie doń podobnymi oraz odmiennymi pozwala na bardziej adekwatne rozpoznanie i oszacowanie ekonomicznego rozwoju Litwy w kontekście historii globalnej. Punktem wyjścia dla tych badań jest neomarksistowska koncepcja kapitalistycznego systemu-świata Immanuela Wallersteina ${ }^{11}$, który jest najbardziej popularnym i wpływowym reprezentantem socjologii historyczno-porównawczej w Stanach Zjednoczonych. Zgodnie z tym ujęciem, litewska i polska gospodarka folwarczno-pańszczyźniana w XVI-XVIII wieku (eksportująca płody rolne do krajów centrum) zaliczana jest do peryferyjnych kapitalistycznych gospodarek, podobnie jak meksykańskie i brazylijskie hacjendy czy niewolnicze plantacje bawełny w Stanach Zjednoczonych w XVIII-XIX wieku ${ }^{12}$. W niniejszym artykule analizie porównawczej poddana będzie gospodarka folwarczno-pańszczyźniana na Litwie z gospodarką hacjendową Ameryki Łacińskiej od II połowy XVIII do II połowy XIX wieku. Prawdopodobnie w tym momencie, zresztą całkiem rozsądnie, nasuwają się pytania: dlaczego akurat gospodarka hacjendowa (a nie plantacji) została wybrana jako podstawa porównania z Litwą i dlaczego właśnie okres od II połowy XVIII do II połowy XIX wieku jest przedmiotem tej analizy? Zarówno system folwarczno-pańszczyźniany na Litwie, jak i hacjendy w Ameryki Łacińskiej oparte były na produkcji wykorzystującej poddańczą siłę roboczą. Hacjenda, oparta głównie na pracy

${ }^{10}$ Badania w tej dziedzinie na Litwie prowadzą: Z. Norkus, Two Periods of the Peripheric Capitalist Development: Pre-Communist and Post-Communist Eastern Europe in Comparison, „Polish Sociological Review” 2(19)/2015, ss. 131-151; idem, A Comparison of the Economic Growth of the Baltic States between the Two World Wars, „World Political Science" 12(1)/2016, ss. 1-23; N. Babinskas, Economic Challenges of the Early Modern Ages and Different Responses of European Margins: Comparative Considertions on the Basis of Historiography (The Cases of Polish-Lithuanian Commonwealth and Moldavian Principality, „Revista Română de Studii Baltice și Nordice” / ”The Romanian Journal for Baltic and Nordic Studies” 4(2)/2012, ss. 51-62; D. Žiemelis, Tipologiškai artimi Lietuvai ūkiai: Čekija, Lenkija, Vengrija ankstyvaisiais Naujaisiais laikais, „Lietuvos istorijos metraštis” 2/2014, ss. 87-116.

${ }^{11}$ Więcej na temat koncepcji kapitalistycznego systemu-świata: D. Chirot, T.D. Hall, World-System Theory, „Annual Review of Sociology” 8/1982, ss. 81-106; K. Brzechczyn, Odrębność historyczna Europy Środkowej. Studium metodologiczne, Wyd. Fundacji Humaniora, Poznań 1998, ss. 16-19.

12 I. Wallerstein, The Modern World-System I: Capitalist Agriculture and the Origins of the European World-Economy in the Sixteenth Century, Academic Press, New York 1974, ss. 67-129. 
przymusowej świadczonej indywidualnie przez chłopstwo użytkujące działki ziemi, jest uznawana za recepcję zachodniej gospodarki feudalnej w Ameryce Łacińskiej. Z tego powodu te dwa systemy gospodarcze, choć funkcjonowały na różnych kontynentach, mogą być postrzegane jako typologicznie podobne. Przedmiotem porównania jest okres od II połowy XVIII do II połowy XIX wieku. Wtedy to nastąpiła intensyfikacja i dominacja gospodarki folwarczno-pańszczyźnianej na Litwie i gospodarki hacjendowej w krajach latynoamerykańskich. W przypadku Litwy okres ten określany jest mianem „wtórnego poddaństwa” ${ }^{13}$, natomiast w Ameryce Łacińskiej - „wtórnego niewolnictwa"14. Najnowsze badania historiograficzne (Dale Tomich, Michael Zeuske) traktują zjawisko wtórnego poddaństwa na terenach położonych na wschód od Łaby jako odpowiednik wtórnego niewolnictwa ${ }^{15}$. Autor niniejszego artykułu w swoich poprzednich badaniach, których przedmiotem był problem stosowania pojęcia wtórnego poddaństwa w historii Europy Środkowo-Wschodniej ${ }^{16}$, doszedł do wniosków, które korygują koncepcję kapitalistycznego systemu-świata Wallersteina. Mianowicie cechy wtórnego poddaństwa (które powinno być pojmowane jako przypadek peryferyjnego kapitalizmu) były najbardziej widoczne i charakterystyczne dla gospodarki litewskiej nie w okresie XVI-XVIII wieku, lecz od II połowy XVIII wieku do 1861 r., tj. podczas drugiego stadium rozwoju systemu folwarczno-pańszczyźnianego ${ }^{17}$. Analiza porównawcza europejskiego systemu folwarcznego i latynoamerykańskiej gospodarki hacjendowej została przeprowadzona

13 Terminu „wtórne poddaństwo” jako pierwszy użył Fryderyk Engels pod koniec XIX wieku, opisując relacje agrarne oparte na gospodarce pańszczyźnianej, która formowała się i stabilizowała od końca XV wieku do XVII wieku na wschód od Łaby. Por. Letter from F. Engels to K. Marx dated December 15, 16 and 22, 1882, w: K. Marx, F. Engels, Briefwechsel 4. Bd.: 1868-1883, Dietz Verlag, Berlin 1950, ss. 691, 693 i 698.

${ }^{14}$ Termin „wtórne niewolnictwo” (opisujący utworzenie się nowej, wysoko wydajnej strefy produkcji niewolniczej w południowych stanach USA, na Kubie i w Brazylii) został wprowadzony do naukowego obiegu przez amerykańskiego socjologa historycznego D. Tomicha. Por. D. Tomich, Through the Prism of Slavery: Labor, Capital, and World Economy, Rowman - Littlefield, Lanham 2004, ss. 56-71.

15 Przesłanką dla tego stwierdzenia była intensyfikacja przymusowej pracy produkcyjnej tych rozwijających się krajów, wywołana podobnymi przyczynami (np. popyt na płody rolne na rynku, zwłaszcza zagranicznym). Por. D. Tomich, M. Zeuske, Introduction, The Second Slavery: Mass Slavery, World-Economy, and Comparative Microhistories, „Review Fernand Braudel Center” 31(2)/2008, ss. 91-100.

${ }^{16}$ A. Kahan, Notes on Serfdom in Western and Eastern Europe, „Journal of Economic History” 33(1)/1973, ss. 86-99.

${ }^{17}$ D. Žiemelis, The Problem of the Application of the Term Second Serfdom in the History of Central Eastern Europe: The Case of Lithuanian Economy in the $16^{\text {th }}-19^{\text {th }}$ Cen- 
przez Cristobala Kaya. Wyjaśnia on strukturę europejskiego folwarku na przykładzie Anglii i wschodnich Niemiec, zaś strukturę południowoamerykańskiej hacjendy - na przykładzie Chile ${ }^{18}$. Dowodzi to, że do tej pory nie zostały zaprezentowane żadne badania porównawcze dotyczące struktury i trendów rozwojowych litewskiej gospodarki folwarczno-pańszczyźnianej i południowoamerykańskiej gospodarki hacjendowej w wybranym przeze mnie okresie.

Dlatego też celem niniejszego artykułu jest sondażowa analiza porównawcza litewskiego systemu folwarczno-pańszczyźnianego i latynoamerykańskiej hacjendy od II połowy XVIII do II połowy XIX wieku w świetle koncepcji kapitalistycznego systemu-świata. Artykuł rozpoczyna się od analizy litewskiego rozwoju gospodarczego w tym okresie w kategoriach peryferyjnego kapitalizmu. Po wyszczególnieniu cech peryferyjnego kapitalizmu zostaną przedstawione najważniejsze podobieństwa i różnice pomiędzy strukturami i tendencjami rozwojowymi gospodarki folwarczno-pańszczyźnianej na Litwie oraz latynoamerykańskiego systemu hacjendowego.

\section{Struktura i ewolucja gospodarki litewskiej od II połowy XVIII do II połowy XIX wieku w świetle koncepcji peryferyjnego kapitalizmu}

Pierwszy tom traktatu Immanuela Wallersteina The Modern World System, który opisuje powstanie i początki kapitalistycznego systemu-świata w XVI wieku, ujmuje społeczno-gospodarczy system Polski i Litwy XVI-XVIII wieku w kategoriach peryferii kapitalistycznego systemu-świata. W tej koncepcji zjawisko wtórnego poddaństwa od XVI do XVIII wieku (dominacja poddaństwa, pojawienie się dużych gospodarstw folwarczno-pańszczyźnianych, których celem produkcyjnym była uprawa i eksport zboża, słaby rozwój miast) jest traktowane jako przejaw kapitalizmu peryferyjnego w Europie Środkowo-Wschodniej (a także Litwy) ${ }^{19}$.

Zacznijmy analizę od problematycznej kwestii - czy możemy zakwalifikować litewską gospodarkę folwarczno-pańszczyźnianą w XVI-XVIII wieku jako „fabrykę zboża” lub „przedsiębiorstwo produkcji rolnej” produkujące

turies (until 1861), „Revista Română de Studii Baltice și Nordice”/,The Romanian Journal for Baltic and Nordic Studies” 7(1)/2015, ss. 123-149.

${ }^{18}$ C. Kay, Comparative Development of the European Manorial System and the Latin American Hacienda System, ,Journal of Peasant Studies” 2(1)/1974, ss. 69-98.

${ }^{19}$ I. Wallerstein, The Modern World-System I..., ss. 67-129. 
na rynek zbytu (szczególnie zagraniczny)? Odpowiedź na to pytanie jest skomplikowana, ponieważ w świetle historiograficznych badań w teorii kapitalistycznego systemu-świata (szczególnie do II połowy XIX wieku) znaczenie wymiany międzynarodowej i globalnych procesów rynkowych dla wewnętrznego rozwoju społecznego i gospodarczego danego kraju jest bardzo przeceniane ${ }^{20}$. Zgodnie z teorią kapitalistycznego systemu-świata główną cechą kapitalizmu peryferyjnego jest zależność gospodarki danego kraju od rynku międzynarodowego ${ }^{21}$. Badania pokazują jednak niski udział gospodarczy Litwy w handlu międzynarodowym w XVI-XVIII wieku². Tu pojawia się drugi problem wskazywany w dyskusji na temat powodów, które doprowadziły do powstania wtórnego poddaństwa w Europie Środkowo-Wschodniej. W tradycyjnej perspektywie marksistowskiej kładzie się większy nacisk na wewnętrzne przyczyny ${ }^{23}$, podczas gdy w kapitalistycznym

${ }^{20}$ P. O’Brien, European Economic Development: The Contribution of the Periphery, „Economic History Review” 35(1)/1982, ss. 1-18; H. Wesseling, Overseas History, w: P. Burke (red.), New Perspectives on Historical Writing, Polity Press, Cambridge 1992, ss. 67-92.

${ }^{21}$ Cechą charakterystyczną kapitalizmu peryferyjnego, zgodnie z koncepcją kapitalistycznego systemu-świata, jest stosowanie pracy przymusowej (niewolnicy, poddani). Słaba państwowość z politycznego i militarnego punktu widzenia lub wynikająca z kolonialnych czy półkolonialnych wpływów może być dystynktywna dla peryferyjnej organizacji politycznej. Klasy posiadające w kapitalistycznych peryferiach składają się z właścicieli niewolników i właścicieli ziemskich, których plantacje i gospodarstwa to zorganizowane w sposób kapitalistyczny przedsiębiorstwa, wytwarzające produkty zarówno na rynek wewnętrzny, jak i zewnętrzny. W globalnym podziale pracy rola „zaopatrzeniowca” w produkcję wydobywczą i rolną dla strefy krajów rdzenia przypada kapitalizmowi peryferyjnemu. Por. I. Wallerstein, The Modern World-System I..., s. 349.

${ }_{22}$ D. Žiemelis, The Structure and Scope of the Foreign Trade of the Polish-Lithuanian Commonwealth in the $16^{\text {th }}$ to $18^{\text {th }}$ Centuries: The Case of the Grand Duchy of Lithuania, „Lithuanian History Studies” 17/2013, ss. 91-123.

${ }^{23}$ Wewnętrzne, społeczno-ekonomiczne przyczyny pojawienia się wtórnego poddaństwa w Europie Środkowo-Centralnej są podkreślane w tradycyjnej historiografii marksistowskiej. Są to przede wszystkim: różnica w społecznej równowadze władzy na rzecz szlachty, słaby rozwój miast, niedobór siły roboczej, duże obszary nieużytków. W tej historiograficznej perspektywie koncepcja drugiego poddaństwa służy do ujęcia procesu ponownej feudalizacji w Europie Środkowo-Wschodniej. Więcej o koncepcji genezy drugiego poddaństwa w tradycyjnej marksistowskiej historiografii i niemarksistowskiej historiografii: B. Zientara, Z zagadnień tzw. „wtórnego poddaństwa” w Europie Środkowej, „Przegląd Historyczny” 47(1)/1956, ss. 3-47; L. Makkai, Neo-Serdom: Its Origin and Nature in East Central Europe, „Slavic Review. American Quarterly of Soviet and East European Studies” 34(2)/1975, ss. 225-238; J. Topolski, Continuity and Discontinuity in the Development of the Feudal System in Eastern Europe ( $X^{\text {th }}$ to XVII ${ }^{\text {th }}$ Centuries), „Journal of European Economic History” 10(2)/1981, ss. 373-400. 
systemie-świecie - na zewnętrzne (udział w hierarchicznym, światowym podziale pracy z uwagi na peryferyjny status). Spór ten rodzi problem zastosowania pojęcia wtórnego poddaństwa w odniesieniu do społeczno gospodarczego porządku Litwy w XVI-XVIII wieku. Badania pokazują, że termin ten nie powinien być stosowany do opisu stosunków agrarnych na Litwie w okresie od XV do XVIII wieku. Zwolennicy tego podejścia (Juozas Jurginis, Wojciech Hejnosz, Arcadius Kahan, Johannes Nichtweiss, Jerzy Topolski, Jūratè Kiaupienė, Alfredas Bumblauskas) uważają, że na Litwie miał miejsce ciągły proces zniewolenia chłopów, który chronologicznie zbiegł się z apogeum nowej, feudalnej „reakcji” w typowych krajach wtórnego poddaństwa (szczególnie na obszarze wschodnich Niemiec) ${ }^{24}$.

Litewska gospodarka folwarczno-pańszczyźniana w XVI-XVIII wieku była zorientowana na prostą produkcję handlową, co zgodnie z tradycyjną historiografią marksistowską wskazuje na jej typowy feudalny charakter. Jednakże diachroniczna analiza porównawcza struktur gospodarczych i tendencji zachodnioeuropejskiej gospodarki dworskiej w okresie XI-XV wieku, a także gospodarki folwarczno-pańszczyźnianej w Europie Środkowo-Wschodniej od XVI do XVIII wieku (a dokładnie w Rzeczypospolitej Obojga Narodów) nie pozwala potraktować gospodarki folwarczno-pańszczyźnianej Litwy (i Polski) jako typowej gospodarki feudalnej. W okresie od XVI do XVIII wieku produkcja gospodarcza litewskiego (i polskiego) folwarku pańszczyźnianego, ze względu na zjawisko nożyc cen, występujące między wewnętrznymi i zewnętrznymi rynkami (wpływ kapitalistycznego systemu-świata), nakierowana była na zewnętrzne rynki. Natomiast zwykła, komercyjna produkcja była zdeterminowana przez działania ekonomiczne właścicieli ziemskich. Osiagane zyski nie były przeznaczane na inwestycje, lecz na zwiększanie konsumpcji elit. Wszystko to wskazuje, że litewska gospodarka folwarczno-pańszczyźniana nie może być uznana za typowe przedsiębiorstwo kapitalizmu peryferyjnego (w ścisłym znaczeniu koncepcji kapitalistycznego systemu-świata ${ }^{25}$. Jednakże, patrząc na rozwój ekonomiczny Litwy w okresie gospodarki folwarczno-pańszczyźnianej (1557-1861), w świetle koncepcji peryferyjnego kapitalizmu, cechy drugie-

${ }^{24}$ D. Žiemelis, The Problem of the Application..., ss. 123-149.

${ }^{25}$ O pierwszym przypadku w historiografii podjęcia diachronicznej analizy porównawczej XI-XV-wiecznych zachodnioeuropejskich struktur gospodarki lennej i XVI-XVIII-wiecznych struktur folwarczno-pańszczyźnianych Europy Środkowo-Wschodniej (szczególnie Rzeczypospolitej Obojga Narodów) oraz tendencji rozwojowych zob. D. Žiemelis, XVI-XVIII amžiaus Abiejų Tautu Respublikos palivarko ūkis marksistiniu bei neoinstitucionalistiniu požiūriu, „Lietuvos istorijos studijos” 27/2011, ss. 11-38. 
go poddaństwa są najbardziej widoczne na Litwie nie w XVI-XVIII wieku (jak twierdzi I. Wallerstein), ale od drugiej połowy XVIII wieku do 1861 r., tj. podczas drugiej fazy rozwoju gospodarki folwarczno-pańszczyźnianej.

W fazie tej system pańszczyźniany, maksymalizując rentę feudalną, osiągnął apogeum swojej ekspansji ${ }^{26}$. W historiografii zjawisko to jest określane mianem renesansu gospodarki folwarczno-pańszczyźnianej ${ }^{27}$. Być może główną przyczyną tego procesu była rewolucja przemysłowa w Europie Zachodniej, która rozpoczynając się pod koniec XVIII wieku, ponownie wpłynęła na wzrost międzynarodowego popytu na zboże i inne produkty rolne ${ }^{28}$.

Na Litwie w II połowie XVIII wieku podjęto próby reform gospodarki folwarcznej w oparciu o ekonomiczne koncepcje fizjokratów. Badania dowodzą, że wpływ idei oświeceniowych na drugą fazę rozwoju litewskiej gospodarki dał (w porównaniu do zmian gospodarki krajów Europy Zachodniej) odwrotne rezultaty - udział pracy pańszczyźnianej w rolnictwie się zwiększył. Zgodnie z tezami Eligijusa Raili po odwiedzeniu wielu krajów europejskich i zapoznaniu się z niektórymi najbardziej postępowymi modelami ekonomicznymi II połowy XVIII wieku, szlachta litewska próbowała jedynie kopiować w swoich majątkach ziemskich zachodnie zasady działań, tj. starała się wprowadzić „giętkie” zasady oświeceniowej przedsiębiorczości i pracy indywidualnej do skostniałego folwarcznego systemu gospodarczego. Struktura życia poddańczego, ignorująca wolność osobistą i gwarantująca ścisłą hierarchię społeczną, była zasadniczo niezdolna do absorbcji ekonomicznego potencjału opartego na pracy i odpowiedzialności wolnych

${ }^{26}$ Na Litwie pańszczyzna wynosiła około 2-3 dni tygodniowo w XVII-XVIII wieku. Por. M. Jučas, Baudžiavos irimas Lietuvoje, Mintis, Vilnius 1972, ss. 40-141. Aż do zniesienia pańszczyzny w 1861 r. liczba dni wzrosła do 5 tygodniowo. Por. S. Pamerneckis, Agrariniu santykiu raida ir dinamika Lietuvoje: XVIII a. pabaiga - XIX a. pirmoji pusé (statistine analizè), Vilniaus universiteto leidykla, Vilnius 2004, s. 120. Wielu badaczy podkreśla, że generalnie do końca XVIII wieku w większości krajów Europy Środkowo-Wschodniej i Wschodniej renta w postaci pańszczyzny była obiektywnym czynnikiem determinującym rozwój gospodarki kraju. Por. S. Pamerneckis, Agrarinių santykių raida..., s. 119; R. Millward, The Early Stages of European Industrialization: Economic Organization under Serfdom, „Explorations in Economic History” 21(4)/1984, ss. 406-428.

${ }^{27}$ M. Jučas, Baudžiavos irimas Lietuvoje..., ss. 103-104; E. Raila, Ignotus Ignotas: Vilniaus vyskupas Ignotas Jokūbas Masalskis, Aidai, Vilnius 2010, ss. 187-188.

${ }^{28}$ R.C. Allen, Economic Structure and Agricultural Productivity in Europe, 13001800, „European Review of Economic History” 4(1)/2000, ss. 1-26; J.G. Williamson, Globalization and the Great Divergence: Terms of Trade Booms, Volatility and the Poor Periphery, 1782-1913, „European Review of Economic History” 12(3)/2008, ss. 355-391. 
jednostek. Jednym z litewskich szlachciców, który popierał te inicjatywy, był Antoni Tyzenhauzas, który „zintensyfikował” folwarczność królewskiej gospodarki, wykorzystując pracę poddańczą. E. Raila trafnie określa taką „intensyfikację folwarczności” jako „reanimację systemu gospodarstw poddańczych poprzez użycie po części technik Europy Zachodniej, a po części stałych metod rolniczych"29.

Po rozpadzie Rzeczypospolitej Obojga Narodów w 1795 r. największa etnograficznie część Litwy, z powodów politycznych oraz przez brak portów, stała się kolonialnymi peryferiami Rosji (która sama z kolei była półperyferią kapitalistycznego systemu-świata). Litwa, jako podwójnie kolonialne peryferia, ukierunkowała swoją gospodarkę nie na przemysł, ale na zaopatrywanie w surowce centrum imperium rosyjskiego i rynek zachodni ${ }^{30}$. Pogłębiło to agraryzację gospodarki litewskiej. Jak wynika z badań Stanislovasa Pamerneckisa, wzrost renty feudalnej w latach 1795-1861 spowodował, że rozwój systemu pańszczyźnianego osiągnął wtedy swój szczytowy punkt ${ }^{31}$. O ostatecznym utrwaleniu gospodarki folwarczno-pańszczyźnianej świadczy fakt, że od II połowy XVIII wieku do 1861 r. struktura litewskiego eksportu, w przeciwieństwie do pierwszego etapu rozwoju gospodarczego Litwy (od połowy XVI do II połowy XVIII wieku) została zdominowana przez sprzedaż zboża, uprawianego głównie w szlacheckich gospodarstwach folwarczno-pańszczyźnianych ${ }^{32}$. Są to typowe cechy wtórnego poddaństwa. Jak twierdzi S. Pamerneckis: „Litwa, wraz z terenami Białorusi, stała się najbardziej konserwatywnym zakątkiem relacji pańszczyźnianych w europejskiej części imperium rosyjskiego"33.

Struktura litewskiej gospodarki i jej ewolucja (pomiędzy II połową XVIII wieku a 1861 r.) w kontekście światowej historii jest najbardziej zbliżona do „idealnego modelu” peryferyjnej kapitalistycznej gospodarki

${ }^{29}$ E. Raila, Ignotus Ignotas..., s. 188.

${ }^{30}$ D. Žiemelis, The Socio-Economic History of Lithuania..., ss. 80-82; Z. Norkus, Kapitalizmo raidos Lietuvoje bruožai ir etapai (iki 1940 m.) postmarksistiniu požiūriu, „Lietuvos istorijos studijos” 29/2012, ss. 21-22.

${ }^{31}$ S. Pamerneckis, Agrariniu santykiu raida..., ss. 81-116.

32 Więcej na temat struktury towarowej litewskiego eksportu i importu w omawianym okresie: В.Ю. Меркис, Экспорт зерна и льна из Литвы в 1795-1861 г2., w: Ежегодник по аграрной истории Восточной Европы 1963 г.: (доклады и сообщения шестой сессии межреспубликанского симпозиума по аграрной истории, состоящегося в г. Вильнюсе с 19 по 24 сентября 1963 г.), Вильнюс 1964, ss. 436-447; D. Žiemelis, The Structure and Scope..., ss. 91-123.

33 S. Pamerneckis, Agrarinių santykiu raida..., s. 120. 
przedstawionej w teorii kapitalistycznego systemu-świata ${ }^{34}$. Przeznaczanie kapitału na wzrost konsumpcji własnej oraz niewielkie zaangażowanie gospodarcze w międzynarodowy rynek, charakterystyczne dla właścicieli folwarczno-pańszczyźnianych majątków ziemskich, uniemożliwiło Litwie pełne przekształcenie się w peryferyjną strefę kapitalizmu. Jakościowy przełom nastąpił po zniesieniu pańszczyzny w $1861 \mathrm{r}$. Jak pokazują badania Zenonasa Norkusa, okres rozwoju gospodarczego Litwy w latach 1861-1914 w pełni reprezentuje typ peryferyjnej, kolonialnej gospodarki kapitalistycznej ${ }^{35}$.

\section{Porównanie struktur ekonomicznych i dynamiki rozwojowej litewskiej gospodarki folwarczno-pańszczyźnianej oraz latynoamerykańskiej hacjendy od II połowy XVIII do II połowy XIX wieku}

Zacznę od zdefiniowania dwóch ustrojów gospodarczych: systemu folwarczno-pańszczyźnianego oraz hacjendowego w celu porównania struktur i dynamiki rozwojowej obu gospodarek opartych na folwarku pańszczyźnianym i hacjendzie w badanym okresie. Po raz pierwszy model gospodarki folwarczno-pańszczyźnianej, zbudowany w oparciu o rozwój polskiego systemu pańszczyźnianego, został zaproponowany przez polskiego historyka gospodarczego Witolda Kulę w 1962 r. w pracy Teoria ekonomiczna ustroju feudalnego. Próba modelu ${ }^{36}$. Jest to obecnie praca klasyczna w dziedzinie historii gospodarczej. W. Kula przypisuje gospodarstwu szlacheckiemu występującemu w systemie folwarczno-pańszczyźnianym, następujące cechy: 1) ekstensywna gospodarka, w której wielkość produkcji zależna była od powierzchni uprawianej ziemi, zaś wielkość powierzchni upraw - od liczby dostępnej siły roboczej; 2) dążenie do optymalnej (dla interesów właściciela ziemskiego) relacji między powierzchnią folwarku a powierzchnią gospodarstw chłopskich; 3) dochód uzyskiwany ze sprzedaży zboża nie był inwestowany, lecz przeznaczany na konsumpcję własną; 4) reprodukcja

${ }^{34}$ Więcej na temat typologicznej oceny historii gospodarki i społeczeństwa Litwy XVI-XIX wieku (do 1861 r.) w kontekście światowej historii, w terminach najbardziej wpływowych koncepcji rozwoju ekonomicznego w: D. Žiemelis, The Socio-Economic History of Lithuania..., ss. 57-90.

${ }_{35}$ Z. Norkus, Kapitalizmo raidos Lietuvoje..., ss. 22-25.

${ }^{36}$ W. Kula, Teoria ekonomiczna ustroju feudalnego. Próba modelu, PWN, Warszawa 1962. 
prosta i ograniczenie inwestowania - inwestycje właściciela mające na celu zwiększenie produktu dodatkowego polegają zazwyczaj na włączeniu gospodarstw chłopskich w obręb swoich włości lub na podniesieniu chłopom renty feudalnej; 5) duże zróżnicowanie wielkości i asortymentu produkcji rolnej spowodowane głównie wydajnością zbiorów, potrzebami konsumpcyjnymi właściciela i w niewielkim stopniu potrzebami rynku. Główny wniosek W. Kuli brzmi: chociaż gospodarka folwarczno-pańszczyźniana (tj. późnofeudalne „przedsiębiorstwo”) była powiązana w pewnym stopniu z krajowym i międzynarodowym rynkiem zbytu, to jej główną cechą była produkcja na własne potrzeby ${ }^{37}$.

Pierwszą definicję hacjendy jako ustroju gospodarczego przedstawili amerykańscy antropolodzy Eric R. Wolf i Sidney W. Mintz. Według nich hacjenda jest posiadłością ziemską specjalizującą się w produkcji rolnej, zarządzaną przez właściciela ziemskiego, który zatrudnia zależną od niego siłę roboczą. Z powodu deficytu kapitału obrotowego produkcja gospodarstwa przeznaczona jest na niewielki (tj. krajowy) rynek zbytu. Zyski z produkcji nie są wykorzystywane wyłącznie do akumulacji kapitału, lecz także do wspierania statusu społecznego właścicieli ziemskich ${ }^{38}$. Podobieństwa i różnice między hacjendą a folwarkiem pańszczyźnianym stają się jeszcze bardziej widoczne poprzez porównanie tych form gospodarowania z plantacjami, które były typologicznie podobne, ale opierały się na odmiennej organizacji systemu pracy w obu Amerykach. Według Wolfa i Mintza plantacja jest posiadłością ziemską specjalizującą się w produkcji rolnej, zarządzaną przez właścicieli (zwykle zorganizowanych korporacyjnie), opartą na zależnej sile roboczej. Z powodu wielkiej powierzchni majątków produkowane dobra są przeznaczone wyłącznie na zagraniczne rynki zbytu, a zyski wykorzystywane przede wszystkim do akumulacji kapitału, a nie zaspokajania potrzeb właścicieli wynikających z ich statusu społecznego ${ }^{39}$. Fundamentalna różnica polega na wykorzystywanej sile roboczej. Hacjenda oparta jest na poddaństwie, zaś plantacja - na pracy niewolniczej. Hacjendy i plantacje w obu Amerykach były efektem powstania globalnej gospodarki w XVI wieku, która zrodziła zapotrzebowanie na produkcję rolną przeznaczoną na rynek zewnętrzny ${ }^{40}$.

${ }^{37}$ W. Kula, An Economic Theory of the Feudal System: Towards A Model of the Polish Economy 1500-1800, tłum. L. Garner, New Left Books, London 1976, ss. 50-83.

${ }^{38}$ E.R. Wolf, S.W. Mintz, Haciendas and Plantations in Middle America and the Antilles, „Social and Economic Studies” 6(3)/1957, s. 380.

${ }^{39}$ Ibidem.

${ }^{40}$ Ibidem, ss. 380-412. 
Latynoamerykańska hacjenda i litewski folwark szlachecko-pańszczyźniany mogą być ujmowanie jako systemy organizacji produkcji rolnej, których główną cechą jest duży areał użytkowanej ziemi będącej w posiadaniu państwa bądź prawnego właściciela. Chłopi, aby móc uprawiać ziemię, musieli przede wszystkim uiścić rentę feudalną. Z instytucjonalnego punktu widzenia w hacjendach nie funkcjonowała żadna umowa regulującą stosunki między właścicielami i chłopami, która tak jak w Europie Zachodniej XI-XV wieku była podstawą stosunków poddaństwa ${ }^{41}$. Zarówno folwark pańszczyźniany, jak i hacjenda oparte były na dominacji pana nad chłopami. Z drugiej strony, podobnie jak w systemie folwarczno-pańszczyźnianym, w hacjendzie podległość chłopa (który mieszkał na słabo zaludnionych terenach, z dala od miasta) względem pana oznaczała również pewnego rodzaju ochronę jego gospodarstwa przed upadłością ${ }^{42}$.

Co spowodowało zatem wprowadzenie uprzywilejowanej pozycji właścicieli ziemskich wobec chłopów i jakimi sposobami zostało ono osiągnięte między II połową XVIII a II połową XIX wieku w krajach Ameryki Łacińskiej? Przyczyny i metody ustanowienia dominacji hacjenderów w strukturze rolnej Ameryki Łacińskiej były niemal identyczne jak procesy prowadzące do powstania gospodarki folwarczno-pańszczyźnianej w Europie Środkowo-Wschodniej w wiekach XVI-XVIII. Słabość miast, niedobór siły roboczej, duże nieużytki ziemskie i peryferyjna pozycja Europy Środkowo-Wschodniej w międzynarodowym podziale pracy w XVI-XVIII wieku zapewniła przewagę szlachty, która mogła wprowadzić i maksymalizować poddaństwo chłopów ${ }^{43}$. Jak pokazałem, w przypadku rozwoju społeczno-gospodarczego

${ }^{41}$ Więcej na temat analizy zachodnioeuropejskiej gospodarki lennej i tendencji jej rozwoju w XI-XV wieku w kontekście instytucjonalizmu: D.C. North, R.P. Thomas, The Rise and Fall of the Manorial System: A Theoretical Model, „Journal of Economic History” 31(4)/1971, ss. 777-803; D.C. North, R.P. Thomas, An Economic Theory of the Growth of the Western World, „Economic History Review” 23(1)/1970, ss. 1-17.

${ }^{42}$ Więcej na temat hacjendy: E.R. Wolf, S.W. Mintz, Haciendas and Plantations..., ss. 391-393. Więcej na temat gospodarki folwarczno-pańszczyźnianej: T. Bairašauskaitė, Bajoro santykis su dvaru XIX a. pirmoje pusẻje: Mykolo Juozapo Römerio (1778-1853) patirtys, „Lietuvos istorijos metraštis” 1/2006, ss. 63-82; J. Mečislovas, Prekyba Lietuvos kaime XVIII a., „Iš Lietuvių kultūros istorijos” 4/1964, ss. 109-122. „Protekcja” pana wobec służących mu chłopów radykalnie odróżnia gospodarkę folwarczno-pańszczyźnianą i hacjendową od modelu gospodarki plantacyjnej. W tym ostatnim osoba należąca do właściciela per se nic nie znaczyła. Na przykład na plantacjach właściciele jako środek do utrzymania dyscypliny pracy często stosowali karę śmierci. Por. E.R. Wolf, S.W. Mintz, Haciendas and Plantations..., s. 395.

43 D. Žiemelis, Feudalism or Peripheral Capitalism?..., ss. 33-36. 
Litwy proces ten osiągnął swój szczytowy punkt w okresie od II połowy XVIII do II połowy XIX wieku. Podobnie przyjmuje się, że wyłonienie się latynoamerykańskich właścicieli ziemskich było spowodowane nie tylko słabym rozwojem miast, dużymi połaciami nieużytków rolnych i podporządkowaną pozycją w międzynarodowym podziale pracy, ale również wpływem kolonialnych instytucji. Większość hacjenderów albo była pochodzenia europejskiego, albo była lojalna wobec władzy kolonialnej ${ }^{44}$.

Latynoamerykańskie hacjendy wyrosły z systemu encomiendy, który istniał w Ameryce Łacińskiej w XVI-XVIII wieku. Encomiendę uznaje się za odmianę zachodnioeuropejskiej feudalnej formy nadawania ziemi w XI-XV wieku, która została przeniesiona z Hiszpanii i Portugalii do krajów Ameryki Łacińskiej ${ }^{45}$. Encomienda stała się systemem nieefektywnym w II połowie XVII wieku, aż całkowicie zniknęła pod koniec XVIII wieku i została zastąpiona przez gospodarkę hacjendową ${ }^{46}$. Być może główny czynnik przekształcający encomiendę w hacjendę był natury wewnętrznej. Jedną z najbardziej znaczących przyczyn tej zmiany był drastyczny spadek liczby Indian, spowodowany kolonialną opresją, który utrzymywał się aż do XVII wieku ${ }^{47}$. Ściślej, aż do połowy XVII wieku Indianie byli główną siłą roboczą w najbardziej znaczącej gałęzi latynoamerykańskiej gospo-

${ }^{44}$ F. Chevalier, Land and Society in Colonial Maxico: The Great Hacienda, University of California Press, Berkeley 1963; S.J. Stein, B.H. Stein, The Colonial Heritage of Latin America: Essays on Economic Dependence in Perspective, Oxford University Press, New York 1970; M. Mörner, Economic Factors and Stratification in Colonial Spanish America with Special Regard to Elites, „Hispanic American Historical Review” 63(2)/ 1983, ss. 335-369.

${ }^{45}$ D. Weeks, European Antecedents of Land Tenures and Agrarian Organization of Hispanic America, „Journal of Land \& Public Utility Economics” 23(1)/1947, ss. 60-75; idem, The Agrarian System of the Spanish American Colonies, „Journal of Land \& Public Utility Economics” 23(2)/1947, ss. 153-168; J. Lockhart, Encomienda and Hacienda: The Evolution of the Great Estate in the Spanish Indies, „Hispanic American Historical Review" 49(3)/1969, ss. 411-429.

46 D.M. Jones, The Importance of the "Hacienda" in $19^{\text {th }}$ Century Otumba and Apan, Basin of Mexico, „Historical Archaeology” 15(2)/1981, ss. 87-116; E. Van Young, Hacienda and Market in Eighteenth-Century Mexico: The Rural Economy of the Guadalajara Region, 1675-1810, University of California Press, Berkeley 1981; K. Spalding, Hacienda-Village Relations in Andean Society to 1830, „Latin American Perspectives” 2(1)/1975, ss. 107-121; W. Dean, Latifundia and Land Policy in Nineteenth-Century Brazil, „Hispanic American Historical Review” 51(4)/1971, ss. 606-625.

${ }^{47}$ Na przykład w jednym z największych krajów Ameryki Łacińskiej, Meksyku, od 1521 do 1605 r. liczba Indian spadła o około 95\% z powodu hiszpańskiej eksploatacji gospodarczej i politycznej opresji. Szerzej: K. Brzechczyn, O wielości linii rozwojowych..., s. 339 . 
darki, która opierała się na encomiendzie - górnictwie ${ }^{48}$. Pozostała część siły roboczej była bardzo trudna do utrzymania, ponieważ ze względu na zwiększone obciążenie, migrowała na tereny, gdzie warunki pracy były względnie korzystne. Kolejną wewnętrzną przyczyną był wzrost popytu na produkty rolne na rynku lokalnym. Popyt na produkty rolne i wzrost kosztów wytwarzania został spowodowany rozwojem miast, które były zamieszkiwane przez nieindiańską ludność ${ }^{49}$. Wywoływało to problem zapewnienia siły roboczej w rolnictwie. Czynniki zewnętrzne wpływały również na oddziaływanie czynników wewnętrznych przekształcających system encomiendy w gospodarkę opartą na hacjendzie. Jeden z najważniejszych czynników zewnętrznych to kryzys gospodarczy XVII wieku, który negatywnie wpłynął na górnictwo - główny sektor gospodarki latynoamerykańskiej ${ }^{50}$. Spadek cen złota i srebra na rynku światowym spowodował zwiększenie wydobycia. Można było tego dokonać tylko za pomocą dalszej intensyfikacji pracy ograniczonej siły roboczej. Z drugiej strony, upadek górnictwa zmienił kierunek inwestycji kapitału. Właściciele kopalń zaczęli je sprzedawać i inwestować otrzymane pieniądze w zakup i tworzenie dużych posiadłości ziemskich, które sprzedawały produkty rolne na wzrastających rynkach miejskich i w okręgach rolniczych ${ }^{51}$. Kolejna zewnętrzna przyczyna, która przyspieszyła ustanowienie i intensyfikację systemu hacjendowego, to zmiana koniunktury w światowym handlu w połowie XVIII wieku. Rewolucja przemysłowa w Europie Zachodniej zwiększyła popyt na produkcję rolną (szczególnie na bawełnę, cukier, kawę, zboże $)^{52}$ na rynku światowym, prowadząc do społecznych i ekonomicznych przemian w obu Amerykach w latach 1780-1888.

${ }^{48}$ P.J. Bakewell, Silver Mining and Society in Colonial Mexico. Zacatecas 1546-1700, Cambridge University Press, Cambridge 1971.

49 I. Altman, Spanish Society in Mexico City after the Conquest, „Hispanic American Historical Review” 71(3)/1991, ss. 413-445; E. Van Young, Urban Market and Hinterland: Guadalajara and Its Region in the Eighteenth Century, „Hispanic American Historical Review” 59(4)/1979, ss. 593-635; R. Boyer, Mexico in the Seventeenth Century: Transition of a Colonial Society, „Hispanic American Historical Review” 57(3)/1977, ss. 455-478.

${ }^{50}$ W. Borah, New Spain's Centutry of Depression, University of California Press, Berkeley 1951; D.A. Brading, Miners and Merchants in Bourbon Mexico, 1763-1810, Cambridge University Press, Cambridge 1971.

51 S.J. Stein, B.H. Stein, The Colonial Heritage of Latin America..., s. 38; M. Mörner, The Spanish American Hacienda: A Survey of Recent Research and Debate, „Hispanic American Historical Review” 53(2)/1973, s. 190.

${ }^{52}$ K. Rönnbäck, Consumers and Slavery: Diversified Markets for Plantation Produce and the Survival of Slavery in the Nineteenth Century, „Review Fernand Braudel Center” 31(1)/2010, ss. 69-88. 
Był to okres wtórnego niewolnictwa, które charakteryzowało się intensyfikacją pracy przymusowej (szczególnie niewolniczej) na nowych terytoriach świata ekonomicznego obu Ameryk (południowa Brazylia, Kuba i zachodnie stany Ameryki Północnej). Okres ten trwał aż do zniesienia niewolnictwa w Brazylii w 1888 r. ${ }^{53}$ Właściciele ziemscy w Ameryce Łacińskiej w celu przystosowania się do koniunktury na międzynarodowym rynku rozwiązali problem siły roboczej, wybierając system hacjendowy opierający się na pracy przymusowej. Podobnie jak w Europie Środkowo-Wschodniej, problem siły roboczej został rozwiązany na dwa sposoby: 1) poprzez silniejsze przywiązanie chłopa do ziemi dworskiej (szczególnie poprzez długi i pracę przymusową), 2) poprzez zawłaszczanie użytkowanej przez nich ziemi ${ }^{54}$.

Mówiąc o źródle i przyczynie intensyfikacji gospodarki hacjendowej w Ameryce Łacińskiej ${ }^{55}$, można wyróżnić dwie grupy krajów. W skład pierwszej grupy wchodzą kraje Ameryki Łacińskiej, w których system hacjendowy powstał najpóźniej, a jego ewolucja była względnie powolna. Kraje te charakteryzowały się gęstym zaludnieniem, żyznymi glebami i stosunkowo wysokim standardem życia, silnymi wspólnotami, które aktywnie walczyły o swoje prawa. Dlatego też właścicielom ziemskim w tych krajach (Peru, Boliwia, Ekwador, Meksyk czy Gwatemala) znacznie trudniej było utworzyć duże posiadłości i zapewnić sobie przymusową siłę roboczą. Kraje należące do drugiej grupy charakteryzowały się niskim zaludnieniem, słabymi wspólnotami i słabo rozwiniętym rolnictwem. Tym samym w krajach należących do tej grupy (Chile, Argentyna, Urugwaj i Brazylia) proces upowszechniania poddaństwa zachodził znacznie szybciej, co spowodowało wczesną (w porównaniu do pierwszej grupy krajów) stabilizację i intensyfikację rozwoju gospodarki hacjendowej.

53 D. Tomich, M. Zeuske, Introduction, The Second Slavery..., ss. 91-100; A.E. Kaye, The Second Slavery: Modernity in the Nineteenth-Century South and the Atlantic World, „Journal of Southern History” 75(3)/2009, ss. 627-650; E.D. Lago, Second Slavery, Second Serfdom, and Beyond: The Atlantic Plantation System and the Eastern and Souther European Landed Estate System in Comparative Perspective, 1800-60, „Review Fernand Braudel Center” 32(4)/2009, ss. 391-420; L.W. Bergad, The Comparative Histories of Slavery in Brazil, Cuba, and the United States, Cambridge University Press, New York 2007.

${ }^{54}$ C. Kay, Comparative Development..., s. 81; E.R. Wolf, S.W. Mintz, Haciendas and Plantations..., ss. 390-391. Więcej na temat przekształcenia chłopów w poddanych w krajach Ameryki Łacińskiej: A.J. Bauer, Rural Workers in Spanish America: Problems of Peonage and Oppression, „Hispanic American Historical Review” 59(1)/1979, ss. 34-63; F. Katz, Labor Conditions on Haciendas in Porfirian Mexico: Some Trends and Tendencies, „Hispanic American Historical Review” 54(1)/1974, ss. 1-47.

55 C. Kay, Comparative Development..., s. 80. 
Ewolucja stosunków agrarnych i ich dynamika na Litwie, zachodząca od II połowy XVIII do II połowy XIX wieku, przypomina rozwój stosunków agrarnych w drugiej grupie krajów - Chile, Argentyny, Urugwaju i Brazylii. Litwa w badanym okresie cechowała się niskim poziomem zaludnienia, niską produktywnością rolną, brakowało też zjednoczonego oporu chłopów wobec właścicieli oraz tradycji walki o swoje prawa. Należy przeprowadzić gruntowną analizę porównawczą (która będzie przedmiotem następnych badań), aby bardziej precyzyjnie określić, w którym kraju (Chile, Argentynie, Urugwaju czy Brazylii) ewolucja relacji agrarnych i ich dynamika były najbardziej zbliżone do ewolucji relacji i dynamiki Litwy ${ }^{56}$. Tutaj jedynie zaznaczę, że struktura eksportu była zdominowana przez handel zbożem zarówno na Litwie, jak i w Chile w pierwszej połowie XIX wieku ${ }^{57}$.

Za największe strukturalne podobieństwo litewskiej gospodarki folwarczno-pańszczyźnianej i gospodarki hacjendowej w omawianym okresie należy uznać przewagę prostej produkcji handlowej. Zorientowanie hacjendy na produkcję przeznaczoną na rynek spowodowane było nie tylko brakiem kapitału, ale również ekonomicznym zachowaniem właścicieli ziemskich. Hacjenderzy nabywali ziemie i siłę roboczą za pomocą pozaekonomicznych środków, więc ich celem nie było, tak jak w przypadku właścicieli niewolniczych plantacji, maksymalizowanie zysków i dalsze inwestowanie ich we wzrost produkcji. Przychody były przeznaczane na luksusową konsumpcję, utrzymanie sieci klientów, wznoszenie budynków o pozaprodukcyjnych funkcjach. Mając na uwadze przeznaczanie zysków na konsumpcję własną w gospodarce ziemskiej w badanym okresie, możemy stwierdzić podobieństwo zachodzące między litewskimi, latynoamerykańskimi i pruskimi właścicielami ziemskimi ${ }^{58}$.

56 Ponadto C. Kay, który porównywał europejski system pańszczyźniany i latynoamerykańską hacjendę w badanym okresie, znajduje najwięcej podobieństw pomiędzy rozwojem relacji agrarnych Prus i Chile. Por. C. Kay, Comparative Development..., ss. 84-86. Więcej na temat podobieństw w rozwoju stosunków agrarnych Chile i Prus: A.J. Bauer, The Hacienda El Huique in the Agrarian Structure of Nineteenth-Century Chile, „Agricultural History” 46(4)/1972, ss. 455-470, Prus i USA: S.D. Bowman, Masters and Lords...

57 В.Ю. Меркис, Экспорт зерна и льна из Литвы..., ss. 436-447; С. Кау, Сотраrative Development..., s. 82.

${ }^{58}$ Więcej na temat konsumpcyjnych praktyk litewskich, latynoamerykańskich oraz pruskich właścicieli ziemskich II połowy XVIII - II połowy XIX wieku: E. Raila, Ignotus Ignotas..., ss. 165-203; S. Pamerneckis, Agrariniu santykiu raida..., s. 111; S. Miller, Mexican Junkers and Capitalist Haciendas, 1810-1910: The Arable Estate and the Transition to Capitalism between the Insurgency and the Revolution, „Journal of Latin American 
Wydajność gospodarki hacjendowej była w części oparta na warunkach działania w sytuacji monopolu aniżeli na warunkach rynkowych. Właściciele ziemscy wytwarzali, obok „,normalnego”, tj. miejskiego (lokalnego) rynku, sztuczny „rynek patrymonialny”, gdzie chłopi byli zmuszani do kupna produktów i usług gospodarstw dworskich ${ }^{59}$. Z drugiej strony praca przymusowa odgrywała ważną rolę w zapewnieniu konkurencyjności produkcji rolnej majątku ziemskiego na normalnym rynku poprzez zmniejszenie kosztów pracy $^{60}$. Można tu zauważyć kolejne podobieństwo między gospodarką folwarczno-pańszczyźnianą a hacjendą oraz ich odmienność od niewolniczych gospodarstw plantacyjnych. W porównaniu z plantacjami gospodarstwa folwarczno-pańszczyźniane i hacjendy były w znacznie mniejszym stopniu zależne od międzynarodowego rynku zbytu, ponieważ były w niego mniej zaangażowane. Gospodarstwa hacjendowe krajów Ameryki Łacińskiej i litewski system folwarczno-pańszczyźniany były zorientowane na produkcję rolną (szczególnie na hodowlę trzody oraz uprawę kukurydzy i zbóż), a w badanym okresie były mało zaangażowane w rynek międzynarodowy. Tylko duże hacjendy stanowiły wyjątek. Było kilka gospodarek hacjendowych nastawionych na eksport na skalę pojedynczego latynoamerykańskiego kraju. Takim wyjątkiem jest Meksyk, który w badanym okresie miał największą, w stosunku do innych krajów Ameryki Łacińskiej, liczbę dużych gospodarstw nastawionych na rynki zagraniczne ${ }^{61}$. Wysoki stopień zaangażowania hacjend latynoamerykańskich w rynek światowy, który wpłynął na jego peryferyjną pozycję w światowej hierarchii podziału pracy, jest obserwowany jedynie od lat 70. XIX wieku².

Produkcja oparta na pracy przymusowej wspierana była również przez kolonialne środowisko instytucjonalne porównywanych krajów. W 1795 r., po włączeniu do imperium rosyjskiego, Litwa została podporządkowana rosyjskiej polityce poddańczej ${ }^{63}$. W porównaniu do Litwy kraje Ameryki Łacińskiej były europejskimi (początkowo hiszpańskimi i portugalskimi)

Studies” 22(2)/1990, ss. 229-263; E.R. Wolf, S.W. Mintz, Haciendas and Plantations..., ss. 386-389; S.D. Bowman, Masters and Lords...

${ }^{59}$ E.R. Wolf, S.W. Mintz, Haciendas and Plantations..., s. 388.

${ }^{60}$ A.J. Bauer, Rural Workers in Spanish America..., ss. 48-59.

${ }^{61}$ A. Knight, Land and Society in Revolutionary Mexico: The Destruction of the Great Haciendas, „Mexican Studies”/„Estudios Mexicanos”7(1)/1991, ss. 73-104; S. Miller, Mexican Junkers and Capitalist Haciendas..., ss. 229-263.

${ }_{62}$ M. Mörner, The Spanish American Hacienda..., ss. 205-207.

${ }^{63}$ Więcej na temat polityki poddańczej w Imperium Rosyjskim: D. Moon, Reassessing Russian Serfdom, „European History Quarterly” 26(4)/1996, ss. 483-526; P. Kolchin, Unfree Labor... 
koloniami już w XVI wieku. Wyzwalanie krajów latynoamerykańskich spod kolonialnych wpływów zaczęło się dopiero w pierwszej połowie XIX wieku. Wpływ środowiska kolonialnego lub uwolnienie się od jego wpływów stwarzały odmienne możliwości dla ruchów chłopskich w Ameryce Łacińskiej i na Litwie. Z powodu zależności od Imperium Rosyjskiego system folwarczno-pańszczyźniany na Litwie ulegał intensyfikacji, a chłopi byli coraz bardziej zależni od właścicieli ziemskich. W tym czasie możliwości migracji chłopstwa, aż do zniesienia pańszczyzny w 1861 r., zostały niemal całkowicie wyeliminowane. W międzyczasie w krajach Ameryki Łacińskiej od lat 20. XIX wieku (z powodu wyzwolenia od zależności kolonialnej) wzrosła swoboda migracji chłopskich. Na przykład chłopi z hacjend w Peru, Boliwii, Ekwadorze, Meksyku i Gwatemali, aby poprawić swoje warunki życiowe, mogli bardziej swobodnie przemieszczać się między posiadłościami lub szukać lepszych warunków pracy w miastach ${ }^{64}$.

W tradycyjnej historiografii marksistowskiej przewaga produkcji przeznaczanej na potrzeby własne świadczy o typowo feudalnej naturze gospodarki. Jednakże produkcja zarówno w litewskiej gospodarce folwarczno-pańszczyźnianej, jak i w hacjendach krajów latynoamerykańskich była nakierowana na rynek. W związku z tym litewska gospodarka folwarczno-pańszczyźniana, jak i gospodarka hacjendowa poszczególnych krajów Ameryki Łacińskiej z uwagi na oddziaływanie gospodarki światowej nie mogą być rozpatrywane jako typowe systemy feudalne. Podejmując się badania przypadku litewskiej gospodarki folwarczno-pańszczyźnianej i południowoamerykańskiej gospodarki hacjendowej, stajemy przed problemem zaklasyfikowania systemu hacjendowego ${ }^{65}$.

W historiografii funkcjonuje wiele określeń na gospodarkę hacjendową krajów Ameryki Łacińskiej od II połowy XVIII do II połowy XIX wieku: zaczątkowe stadium kapitalizmu, okres przejściowy od feudalizmu do kapitalizmu itp. ${ }^{66}$ Jednakże twierdzimy, że gospodarka hacjendowa krajów

${ }^{64}$ C. Kay, Comparative Development..., s. 83.

${ }^{65}$ Ponadto nie ma do tej pory dysputy w historiografii rozważającej ujmowanie niewolniczych plantacji w kategoriach spółek kapitalistycznych. Zob.: E.R. Wolf, S.W. Mintz, Haciendas and Plantations..., ss. 396-407; E.D. Genovese, The Significance of the Slave Plantation for Southern Economic Development, „Journal of Southern History” 28(4)/1962, ss. 422-437.

${ }^{66}$ A.G. Frank, Capitalism and Underdevelopment in Latin America: Historical Studies of Chile and Brazil, Monthly Review Press, New York 1967; E.J. Hobsbawm, A Case of Neo-Feudalism: La Convencion, Peru, „Journal of Latin American Studies” 1(1)/1969, ss. 31-50; E. Laclau, Feudalism and Capitalism in Latin America, „New Left Review” 67/1971, ss. 19-38; C. Henfrey, Dependency, Modes of Production, and the Class Analy- 
latynoamerykańskich, podobnie jak gospodarka folwarczno-pańszczyźniana Litwy w rozważanym okresie, nie była typową gospodarką feudalną ani też peryferyjnym kapitalistycznym przedsięwzięciem (w ścisłym rozumieniu koncepcji kapitalistycznego systemu-świata) i miała cechy kapitalizmu peryferyjnego. Według najbardziej znanych badaczy latynoamerykańskich hacjend, Monera Mangusa i Erika Van Younga, hacjenda jako system gospodarczy miała kapitalistyczny, ale jako system społeczny - feudalny charakter ${ }^{67}$.

\section{Wnioski}

Funkcjonowanie gospodarki folwarczno-pańszczyźnianej na Litwie do 1861 r. jest uważane w historiografii za anachronizm ze względu na rozwój gospodarczy Europy Zachodniej. Jednakże perspektywa porównawcza podkreśliła jego „naturalność” w krajach zacofanych. Starałem się pokazać, że gospodarka oparta na poddaństwie na Litwie i w krajach Ameryki Łacińskiej w omawianym okresie była jedynym możliwym czynnikiem rozwoju ekonomicznego.

Badania ukazały różne źródła dominacji analizowanych systemów gospodarczych. Od II połowy XVIII do II połowy XIX wieku miał miejsce okres intensyfikacji i dominacji litewskiego systemu folwarczno-pańszczyźnianego, który był kontynuacją systemu folwarczno-pańszczyźnianego od XVI do połowy XVIII wieku, posiadającego cechy wtórnego poddaństwa. Gospodarka hacjendowa II połowy XVIII - II połowy XIX wieku jest wynikiem przekształcenia encomiendy (XVI wiek - połowa XVIII wieku). To rewolucja przemysłowa przyniosła dominację systemu pańszczyźnianego i hacjendowego, co doprowadziło do zjawiska wtórnego niewolnictwa w obu Amerykach. Latynoamerykańscy właściciele ziemscy, odczuwający niedobór kapitału potrzebnego do pozyskiwania środków produkcji (takich jak niewolnicy) i próbujący dostosować się do wymagań międzynarodowe-

sis of Latin America, „Latin American Perspectives” 8(3/4)/1981, ss. 17-54; R. Romano, American Feudalism, „Hispanic American Historical Review” 64(1)/1984, ss. 121-134; S.J. Stern, Feudalism, Capitalism, and the World-System in the Perspective of Latin America and the Caribbean, „American Historical Review” 93(4)/1988, ss. 829-872; S. Miller, Mexican Junkers and Capitalist Haciendas..., ss. 229-263.

${ }^{67}$ M. Mörner, The Spanish American Hacienda..., ss. 210-212; E. Van Young, Mexican Rural History Since Chevalier: The Historiography of the Colonial Hacienda, „Latin American Research Review” 18(3)/1983, s. 21. 
go rynku, rozwiązali problem braku siły roboczej, rozwijając gospodarkę hacjendową, opartą na pracy przymusowej.

Analiza pokazuje, że litewska gospodarka folwarczno-pańszczyźniana i latynoamerykańska gospodarka hacjendowa omawianego okresu oparta była na absolutnej dominacji właścicieli ziemskich (zarówno państwowych, jak i prywatnych) nad chłopami. Chłopi byli przede wszystkim zobligowani do płacenia renty feudalnej w zamian za możliwość uprawiania ziemi. Pojawienie się właścicieli ziemskich w krajach latynoamerykańskich było spowodowane nie tylko słabą pozycją miast, dużymi obszarami nieużytków czy uwikłaniem w międzynarodowy podział pracy w związku ze statusem peryferyjnym (pojawienie się litewskich właścicieli ziemskich miało te same powody), ale również instytucjonalnym środowiskiem kolonialnym. Większość właścicieli hacjend albo była z pochodzenia Europejczykami, albo popierała politykę kolonialną.

Analiza porównawcza rozważanych struktur i tendencji rozwojowych litewskiego systemu folwarczno-pańszczyźnianego i latynoamerykańskiego systemu hacjendowego od II połowy XVIII do II połowy XIX wieku nie pozwala zakwalifikować tych systemów, wymuszonych przez zmianę kapitalistycznych relacji Europy Zachodniej, ani jako typowe gospodarki feudalne (jak średniowieczne zachodnioeuropejskie gospodarstwa dworskie), ani jako typowe kapitalistyczne spółki peryferyjne (w ścisłym ujęciu neomarksistowskiej koncepcji kapitalistycznego systemu-świata). Oba systemy rolne były zdominowane przez zwykłą produkcję handlową, która w tradycyjnej marksistowskiej perspektywie jest cechą typowej gospodarki feudalnej. Jednakże produkcja zarówno w litewskiej gospodarce folwarczno-pańszczyźnianej, jak i w latynoamerykańskiej gospodarce hacjendowej, ukształtowana przez konsumpcyjne potrzeby właścicieli ziemskich, była zorientowana na rynek zbytu z powodu wpływu światowej gospodarki. Brak kapitału potrzebnego do zorganizowania produkcji na dużą skalę prowadził do słabego zaangażowania tych gospodarek w światowy rynek. Wszystko to pokazuje, że gospodarka folwarczno-pańszczyźniana na Litwie i gospodarka hacjendowa krajów Ameryki Łacińskiej wykazywała cechy kapitalistycznych peryferii (tj. zastosowanie pracy przymusowej w produkcji, polityczna i gospodarcza zależność kolonialna, status peryferii w globalnym podziale pracy, pozostałości produkcji pańszczyźnianej i hacjendowej w strukturze eksportu), które przeplatały się z pozostałościami gospodarki feudalnej (jedna z nich to przeznaczanie kapitału na konsumpcję własną właścicieli folwarków i hacjend). 


\section{Literatura}

Allen R.C., Economic Structure and Agricultural Productivity in Europe, 1300-1800, „European Review of Economic History” t. 4, 1/(2000).

Altman I., Spanish Society in Mexico City after the Conquest, „Hispanic American Historical Review” t. 71, 3/1991.

Antanaitis K., Sovietiné Lietuvos, Latvijos ir Estijos nomenklatūra (1953-1990 m.): désningumai ir ypatumai. Daktaro disertacija, humanitariniai mokslai, istorija (05 H), Vytauto Didžiojo Universitetas, Kaunas 2001.

Anušauskas A., Ginkluotos kovos dèl Baltijos šalių ir Vakarų Ukrainos nepriklausomybės lyginamoji analizé, „Genocidas ir rezistencija” t. 2, 1997.

Babinskas N., Moldova XIV a. viduryje - XVI a. viduryje kaip socialinès struktūros tipologijos problema. Daktaro disertacija, humanitariniai mokslai, istorija (05 H), Vilniaus Universitetas Vilnius 2010.

Babinskas N., Economic Challenges of the Early Modern Ages and Different Responses of European Margins: Comparative Considerations on the Basis of Historiography (The Cases of Polish-Lithuanian Commonwealth and Moldavian Principality, „Revista Română de Studii Baltice și Nordice / The Romanian Journal for Baltic and Nordic Studies” t. 4 (2)/2012.

Bairašauskaitė T., Bajoro santykis su dvaru XIX a. pirmoje pusëje: Mykolo Juozapo Römerio (1778-1853) patirtys, „Lietuvos istorijos metraštis” 2006, t. 1.

Bakewell P.J., Silver Mining and Society in Colonial Mexico. Zacatecas 1546-1700, Cambridge University Press, Cambridge 1971.

Bauer A.J., The Hacienda El Huique in the Agrarian Structure of Nineteenth-Century Chile, „Agricultural History” t. 46, (4)/1972.

Bauer A.J., Rural Workers in Spanish America: Problems of Peonage and Oppression, „Hispanic American Historical Review” t. 59, 1/1979.

Bergad L.W., The Comparative Histories of Slavery in Brazil, Cuba, and the United States, Cambridge University Press, New York 2007.

Biernacki R., The Fabrication of Labor: Germany and Britain 1640-1914, University of California Press, Berkeley 1995.

Boyer R., Mexico in the Seventeenth Century: Transition of a Colonial Society, „Hispanic American Historical Review” t. 57, 3/1977.

Borah W., New Spain's Centutry of Depression, University of California Press, Berkeley 1951.

Bowman D.S., Masters and Lords: Mid-19th-Century U.S. Planters and Prussian Junkers, Oxford University Press, New York 1993.

Brading D.A., Miners and Merchants in Bourbon Mexico, 1763-1810, Cambridge University Press, Cambridge 1971.

O’Brien P., European Economic Development: The Contribution of the Periphery, „Economic History Review” t. 35, 1/1982.

Brzechczyn K., Odrębność historyczna Europy Środkowej. Studium metodologiczne, Wydawnictwo Fundacji Humaniora, Poznań 1998. 
Brzechczyn K., O wielości linii rozwojowych w procesie historycznym. Próba interpretacji ewolucji społeczeństwa meksykańskiego, Wydawnictwo Naukowe UAM, Poznań 2004.

Brzechczyn K., Wzorce postkomunistycznej transformacji. Artykuł recenzyjny, „Środkowo europejskie Studia Polityczne” 4/2014.

Bumblauskas A., Wielkie Księstwo Litewskie: wspólna historia, podzielona pamięć, Muzeum Historii Polski, Warszawa 2013.

Butkus, Z., Valstybiniai perversmai Baltijos šalyse (1926 ir 1934 m.): panašumai ir skirtumai, „Lietuvos istorijos studijos” t. 18, 2006.

Chevalier F., Land and Society in Colonial Mexico: The Great Hacienda, University of California Press, Berkeley 1963.

Chirot D., T.D. Hall, World-System Theory, „Annual Review of Sociology” t. 8, 1982.

Dean, W. Latifundia and Land Policy in Nineteenth-Century Brazil, „Hispanic American Historical Review” t. 51, 4/ 1971.

Engels F., 'Letter from F. Engels to K. Marx dated December 15, 16 and 22, 1882', w: K. Marx, F. Engels, Briefwechsel 4. Bd.: 1868-1883, Dietz Verlag, Berlin 1950.

Frank A.G., Capitalism and Underdevelopment in Latin America: Historical Studies of Chile and Brazil, Monthly Review Press, New York 1967.

Genovese E.D., The Significance of the Slave Plantation for Southern Economic Development, „Journal of Southern History” t. 28, 4/1962.

Gudavičius E., Lietuvos istorija, t. 1: Nuo seniausių laiku iki 1569 metu, Lietuvos rašytojų sajungos leidykla, Vilnius 1999.

Henfrey C., Dependency, Modes of Production, and the Class Analysis of Latin America, „Latin American Perspectives” t. 8, 3-4/1981.

Hobsbawm E.J., A Case of Neo-Feudalism: La Convencion, Peru, „Journal of Latin American Studies” t. 1, 1/1969.

Jones D.M., The Importance of the „Hacienda” in 19th Century Otumba and Apan, Basin of Mexico, „Historical Archaeology” t. 15, 2/1981.

Jučas M., Baudžiavos irimas Lietuvoje, Mintis, Vilnius 1972.

Kahan A., Notes on Serfdom in Western and Eastern Europe, „Journal of Economic History” t. 33, 1/1973.

Kay C., Comparative Development of the European Manorial System and the Latin American Hacienda System, „Journal of Peasant Studies” t. 2, 1/ 1974.

Kaye A.E., The Second Slavery: Modernity in the Nineteenth-Century South and the Atlantic World, „Journal of Southern History” t. 75, 3/2009.

Katz F., Labor Conditions on Haciendas in Porfirian Mexico: Some Trends and Tendencies, „Hispanic American Historical Review” t. 54, 1/1974.

Knight A., Land and Society in Revolutionary Mexico: The Destruction of the Great Haciendas, „Mexican Studies / Estudios Mexicanos” t. 7, 1/ 1991.

Kolchin P., Unfree Labor: American Slavery and Russian Serfdom, Belknap Press of Harvard University Press, Cambridge, MA 1987.

Kula W., Teoria ekonomiczna ustroju feudalnego: Próba modelu, Państwowe Wydawnictwo Naukowe, Warszawa 1962.

Kula W., An Economic Theory of the Feudal System: Towards A Model of the Polish Economy 1500-1800, z polskiego przetłumaczył L. Garner, New Left Books, London 1976.

Laclau E., Feudalism and Capitalism in Latin America, „New Left Review” t. 67, 1971. 
Lago E.D., Second Slavery, Second Serfdom, and Beyond: The Atlantic Plantation System and the Eastern and Souther European Landed Estate System in Comparative Perspective, 1800-60, „Review (Fernand Braudel Center)” t. 32, 4/ 2009.

Lockhart J., Encomienda and Hacienda: The Evolution of the Great Estate in the Spanish Indies, „Hispanic American Historical Review” t. 49, 3/1969.

Makkai L., Neo-Serdom: Its Origin and Nature in East Central Europe, „Slavic Review. American Quarterly of Soviet and East European Studies” t. 34, 2/1975.

Marx A.W., Making Race and Nation: A Comparison of South Africa, the United States, and Brazil, Cambridge University Press, Cambridge 1998.

Mečislovas J., Prekyba Lietuvos kaime XVIII a., „Iš Lietuvių kultūros istorijos” t. 4, 1964.

Меркис В.Ю., Экспорт зерна и льна из Литвы в 1795-1861 г2., w: Ежегодник по аграрной истории Восточной Европы 1963 г.: (доклады и сообщения шестой сессии межреспубликанского симпозиума по аграрной истории, состоящегося в г. Вильнюсе с 19 по 24 сентября 1963 г.), Вильнюс 1964.

Miller S., Mexican Junkers and Capitalist Haciendas, 1810-1910: The Arable Estate and the Transition to Capitalism between the Insurgency and the Revolution, „Journal of Latin American Studies” t. 22, 2/1990.

Millward R., The Early Stages of European Industrialization: Economic Organization under Serfdom, „Explorations in Economic History” t. 21, 4/1984.

Moon D., Reassessing Russian Serfdom, „European History Quarterly” t. 26, 4/1996.

Mörner M., The Spanish American Hacienda: A Survey of Recent Research and Debate, „Hispanic American Historical Review” t. 53, 2/1973.

Mörner M., Economic Factors and Stratification in Colonial Spanish America with Special Regard to Elites, „Hispanic American Historical Review” t. 63, 2/1983.

Norkus Z., The Grand Duchy of Lithuania in the Retrospective of Comparative Historical Sociology of Empires, „World Political Science Review” t. 3, 4/2007.

Norkus Z., Kokia demokratija, koks kapitalizmas? Pokomunistiné transformacija Lietuvoje lyginamosios istorinés sociologijos požiūriu, Vilniaus universiteto leidykla, Vilnius 2008.

Norkus Z., Imperium litewskie w międzyjednostkowych społecznościach i systemach politycznych: studium przypadku, „Politeja” 2/2011.

Norkus Z., Kapitalizmo raidos Lietuvoje bruožai ir etapai (iki 1940 m.) postmarksistiniu požiūriu, „Lietuvos istorijos studijos” t. 29, 2012.

Norkus Z., On Baltic Slovenia and Adriatic Lithuania. A Qualitative Comparative Analysis of Patterns in Post-Communist Transformation, Apostrofa / CEU Press, Vilnius 2012.

Norkus Z., Two Periods of the Peripheric Capitalist Development: Pre-Communist and PostCommunist Eastern Europe in Comparison, „Polish Sociological Review” t. 2, 19/2015.

Norkus Z., A Comparison of the Economic Growth of the Baltic States between the Two World Wars, „World Political Science” t. 12, 1/2016.

Норкус 3., Непроголошена імперія: Велике князівство Литовське з погляду порівняльноісторичної соціології імперій, Критика, Київ 2016.

North D.C., Thomas R.P., An Economic Theory of the Growth of the Western World, „Economic History Review” t. 23, 1/1970.

North D.C., Thomas R.P., The Rise and Fall of the Manorial System: A Theoretical Model, „Journal of Economic History” t. 31, 4/1971. 
Pamerneckis S., Agrarinių santykių raida ir dinamika Lietuvoje: XVIII a. pabaiga - XIX a. pirmoji pusé (statistiné analizé), Vilniaus universiteto leidykla, Vilnius 2004.

Pivoras S., Lietuvių ir latviu pilietinès savimonès raida: XVIII a. pabaiga - XIX a. pirmoji pusè (lyginamasis aspektas), Vytauto Didžiojo universiteto leidykla, Vilnius 2000.

Pomeranz K., The Great Divergence: China, Europe, and the Making of the Modern World Economy, Princeton University Press, Princeton 2000.

Przeworski A., Democracy and the Market: Political and Economic Reforms in Eastern Europe and Latin America, Cambridge University Press, Cambridge 1991.

Raila E., Ignotus Ignotas: Vilniaus vyskupas Ignotas Jokūbas Masalskis, Aidai, Vilnius 2010.

Romano R., American Feudalism, „Hispanic American Historical Review” t. 64, 1/1984.

Rönnbäck K., Consumers and Slavery: Diversified Markets for Plantation Produce and the Survival of Slavery in the Nineteenth Century, „Review (Fernand Braudel Center)” t. $31,1 / 2010$.

Silberman B.S., Cages of Reason: The Rise of the Rational State in France, Japan, the United States, and Great Britain, University of Chicago Press, Chicago 1993.

Skocpol T., States and Social Revolutions: A Comparative Analysis of France, Russia, and China, Cambridge University Press, Cambridge 1979.

Spalding K., Hacienda-Village Relations in Andean Society to 1830, „Latin American Perspectives" t. 2, 1/1975.

Stein S.J., Stein B.H., The Colonial Heritage of Latin America: Essays on Economic Dependence in Perspective, Oxford University Press, New York 1970.

Stern S.J., Feudalism, Capitalism, and the World-System in the Perspective of Latin America and the Caribbean, „American Historical Review” t. 93 4/1988.

Tomich D., Through the Prism of Slavery: Labor, Capital, and World Economy, Rowman and Littlefield, Lanham - MD 2004.

Tomich D., Zeuske M., Introduction, The Second Slavery: Mass Slavery, World-Economy, and Comparative Microhistories, „Review (Fernand Braudel Center)” t. 31, 2/2008.

Topolski J., Continuity and Discontinuity in the Development of the Feudal System in Eastern Europe ( $X$ th to XVII th Centuries), „Journal of European Economic History” t. $10,2 / 1981$.

Young E. Van, Urban Market and Hinterland: Guadalajara and Its Region in the Eighteenth Century, „Hispanic American Historical Review” t. 59, 4/1979.

Young E. Van, Hacienda and Market in Eighteenth-Century Mexico: The Rural Economy of the Guadalajara Region, 1675-1810, University of California Press, Berkeley 1981.

Young E. Van, Mexican Rural History Since Chevalier: The Historiography of the Colonial Hacienda, „Latin American Research Review” t. 18, 3/1983.

Wallerstein I., The Modern World-System I: Capitalist Agriculture and the Origins of the European World-Economy in the Sixteenth Century, Academic Press, New York 1974.

Weeks D., European Antecedents of Land Tenures and Agrarian Organization of Hispanic America, „Journal of Land \& Public Utility Economics” t. 23, 1/1947.

Weeks D., The Agrarian System of the Spanish American Colonies, „Journal of Land \& Public Utility Economics” t. 23, 2/1947.

Wesseling H., Overseas History, w: P. Burke (red.), New Perspectives on Historical Writing, Polity Press, Cambridge 1992. 
Williamson J.G., Globalization and the Great Divergence: Terms of Trade Booms, Volatility and the Poor Periphery, 1782-1913, „European Review of Economic History” t. 12, 3/2008.

Wolf E.R., Mintz S.W., Haciendas and Plantations in Middle America and the Antilles, „Social and Economic Studies” t. 6, 3/1957.

Zientara B., Z zagadnień tzw. „wtórnego poddaństwa“ w Europie Środkowej, „Przegląd Historyczny” t. 47, 1/1956.

Žiemelis D., Feudalism or Peripheral Capitalism?: Socio-Economic History of the PolishLithuanian Commonwealth in the 16th-18th Centuries, Lap Lambert Academic Publishing GmbH \& Co. KG, Saarbrücken 2011.

Žiemelis D., XVI-XVIII amžiaus Abieju Tautų Respublikos palivarko ūkis marksistiniu bei neoinstitucionalistiniu požiūriu, „Lietuvos istorijos studijos” t. 27, 2011.

Žiemelis D., The Structure and Scope of the Foreign Trade of the Polish-Lithuanian Commonwealth in the 16th to 18th Centuries: The Case of the Grand Duchy of Lithuania, „Lithuanian History Studies” t. 17, 2013.

Žiemelis D., The Socio-Economic History of Lithuania from the 16th to the 19th Century (until 1861) from the Perspective of Economic Development Concepts, „Revista Română de Studii Baltice și Nordice / The Romanian Journal for Baltic and Nordic Studies”, t. 5, 2/2013.

Žiemelis D., Tipologiškai artimi Lietuvai ūkiai: Čekija, Lenkija, Vengrija ankstyvaisiais Naujaisiais laikais, „Lietuvos istorijos metraštis” t. 2, 2014.

Žiemelis D., The Problem of the Application of the Term Second Serfdom in the History of Central Eastern Europe: The Case of Lithuanian Economy in the 16th-19th Centuries (until 1861), „Revista Română de Studii Baltice și Nordice / The Romanian Journal for Baltic and Nordic Studies” t. 7, 1/2015. 